\title{
Territorial Planning for Coastal Zones in Chile: The Need for Geographical-Environmental and Natural Risk Indicators for Spatial Decision Support Systems
}

\author{
Fernando Peña-Cortés ${ }^{1}$, Daniel Rozas-Vásquez ${ }^{1}$, Gonzalo Rebolledo ${ }^{1}$, \\ Jimmy Pincheira-Ulbrich ${ }^{1,2}$, Miguel Escalona ${ }^{1}$, Enrique Hauenstein ${ }^{3}$, \\ Luis Vargas-Chacoff ${ }^{4}$, Carlos Bertrán ${ }^{4}$ Jaime Tapia $^{5}$, Marco Cisternas ${ }^{6}$ \\ ${ }^{1}$ Laboratorio de Planificación Territorial, Núcleo de Investigación en Estudios Ambientales, \\ Universidad Católica de Temuco, Temuco, Chile \\ ${ }^{2}$ Programa de Doctorado en Sistemática y Biodiversidad, Universidad de Concepción, Concepción, Chile \\ ${ }^{3}$ Escuela de Ciencias Ambientales, Facultad de Recursos Naturales, Universidad Católica de Temuco, Temuco, Chile \\ ${ }^{4}$ Instituto de Ciencias Marinas y Limnológicas, Universidad Austral de Chile, Valdivia, Chile \\ ${ }^{5}$ Instituto de Química de Recursos Naturales, Universidad de Talca, Talca, Chile \\ ${ }^{6}$ Escuela de Ciencias del Mar, Pontificia Universidad Católica de Valparaíso, Valparaíso, Chile \\ Email: fpena@uct.cl
}

Received June 16, 2013; revised July 23, 2013; accepted August 12, 2013

Copyright (C) 2013 Fernando Peña-Cortés et al. This is an open access article distributed under the Creative Commons Attribution License, which permits unrestricted use, distribution, and reproduction in any medium, provided the original work is properly cited.

\begin{abstract}
Coastal zones are very dynamic and fragile environments, constituting a landscape ever more heterogeneous, fragmented and with increasing levels of complexity due to the changing relationship between man and nature. Integrated coastal zone management therefore requires detailed knowledge of the system and its components, based - to a large extent - on technical and scientific information. However, the information generated must be in line with the political requirements necessary for decision-making and planning. Thus the use of indicators to give a simplified view of the many components of the territory, and at the same time to provide important information about patterns or trends, becomes a tool of the utmost importance. These indicators can be understood as measurable characteristics of the environment, which facilitate comprehension of the processes occurring at different scales and serve as a reference to inform the population and support decision-making. The aim of the present note is to demonstrate briefly the need to develop geographical-environmental and natural risk indicators to facilitate comprehension of the dynamic of spatial and temporal landscape patterns, particularly in coastal environments. This approach offers an historical summary of the natural, socio-economic and political processes which currently make up the territory, and which without doubt will continue to influence it in the future. At the same time, it is proposed that information should be integrated on the basis of this framework with a view to generating spatial decision support systems in a context of planning and integrated management of the coastal zones of Chile.
\end{abstract}

Keywords: Coastal Zone; Territorial Planning; Indicators; Spatial Decision Support System; Chile

\section{Introduction}

Landscape is understood as a complex, open, spatialtemporal system, which originates and evolves at the interface between nature and society in a constant state of exchange of energy, matter and information. These exchanges define its structure, function, dynamics and evolution [1]. As a product of these multidimensional flows, landscape may be considered to be a representative indicator for environmental analysis, given its connotation of perceptual synthesis, on a human scale, of the system of ecological relationships in the territory [2]. Various study focuses, principally from geographical and ecological sciences, have developed its analysis, leading to integrating concepts oriented towards understanding of this organization and its evolutionary process, characterising spatial patterns, and determining factors and impacts on natural systems [3-5].

In this sense, the tools and techniques developed for studying landscape seek to answer important questions, referring principally to the spatial patterns and evolu- 
tionary processes which determine current structure, as well as the factors and/or processes responsible for these spatial organizations. Furthermore, landscape as spatial reality and ecological structure is in constant evolution or change, thus the elements which modify this landscape may be numerous, conditioned by human factors or natural phenomena [6].

The aim of the present note is to briefly demonstrate the need to develop geographical-environmental and natural risk indicators based on comprehension of the dynamics of spatial and temporal landscape patterns, particularly in coastal environments. This focus offers an historical summary of the natural, socio-economic and political processes which currently make up the territory, and which without doubt will continue to influence it in the future. At the same time, on the basis of this framework, it is proposed that information should be integrated with a view to generating spatial decision support systems in a context of planning and integrated management of the coastal zones of Chile.

\section{Coastal Zones}

Coastal zone systems are highly dynamic in response to natural processes. In some cases these processes may be destructive, like the earthquakes followed by tsunamis which struck Chile in 1960 and 2010, Sumatra-Andaman in 2004 and Japan in 2011 [7-10]. These events without doubt modify the coastal landscape, mainly in terms of its geomorphological evolution through severe erosion as well as subsidence and/or coseismic uplift [97]. This situation leads to the formation of new landscape units such as wetlands and estuaries (in the case of subsidence) and areas available for farmland or other land uses (in the case of uplift). In addition, modifications may be observed in the coastline, dunes and floodplains, altering the original structure and functions of the landscape and human activities as a whole, often with important economic implications. Another of the effects generated by these natural processes is the accumulation of debris, possibly millions of $\mathrm{m}^{3}$ over the flooded area, causing serious geographical-environmental problems such as soil and groundwater contamination, sanitary emergencies, etc [98].

In addition to natural processes, these spaces are also subject to growing anthropic pressure and environmental degradation, with a series of conflicts derived from the use of and access to resources, products and services which are important for man [11].

In these spaces, the presence of unique ecosystems, the complexity and fragility of the landscape, the historicalcultural link with human development and their economic importance $[12,13]$, have led to the development of interdisciplinary, holistic study focuses which seek to integrate social, economic and environmental factors in order to determine optimum use (e.g. [14]). These characteristics are configured by their unique climate, hydrology and geomorphology [15], especially in more natural areas, making these spaces very valuable from the ecologicalenvironmental point of view and particularly attractive for human settlement [16]. This particular set of conditions gives rise to a growing interest in the spatial planning of coastal zones, with the aim of balancing the numerous demands on the land and preventing the effects of natural hazards.

\section{Geographical-Environmental Perspective and Development of Indicators for Planning and Integrated Management of Coastal Zones}

The concept of integrated coastal zone management (ICZM) arose during the Río de Janeiro Summit in 1992, and became definitely established through Agenda 21. ICZM is defined as management of a coastal space under a focus of balanced integration of all its components, including its geographical and political limits, with the final objective of achieving sustainable planning [17]. However, although ICZM requires detailed scientific knowledge of the dynamic and the complexity of the territorial system, it must be aligned to the political requirements necessary for decision-making [18].

Thus the use of indicators to allow a simplified view of the many components of the coastal space, and at the same time to provide important information about patterns, trends or the level of ICZM implementation, becomes a tool of the utmost importance for political action [19]. Geographical-environmental indicators may therefore be understood as measurable characteristics of the environment which facilitate comprehension of the processes occurring at different scales and serve as references for decision-making [20-22]. Indicators are defined as "geographical" and "environmental" to emphasize the fact that they focus not only on the ecological condition of the territorial system, but also its social, cultural and economic dynamic in a spatial context. The indicators help us to understand how human and/or natural systems operate, and the type or intensity of the interactions between their various components [23]. They also offer a perspective on how human activities affect the sustainable development of territories, often degrading their environmental, social and cultural attributes. Thus indicators support scientific, political and citizen actions to monitor the current state of, and changes to, key geographical-environmental components in order to assess as accurately as possible the consequences of the actions and inactions of decision-makers.

In recent years, the use of indicators of this type has acquired great importance in the context of environmental impact evaluation [24], strategic environmental 
evaluation [22], and the preparation of environmental status reports [25], etc. This has considerably increased the influence of indicators in policy drafting and decision-making on a wide range of scales, although without doubt the scientific bases for their selection and preparation could still be significantly improved [21]. Indicators allow the complex comportment of an environmental system to be characterised concisely and comprehensibly, using only a few, easily measured characteristics. Identifying these characteristics facilitates the interpretation of the current state of the components of a territory, allowing the forces for change which have led to the current situation of the system to be identified, and the future direction of not immediately detectable phenomena to be projected.

Table 1 presents a summary of a number of applications of indicators for geographical representation used in different parts of the world, with their context, spatial scale and object. Some authors have used a considerable set of indicators, however in the table we give examples of only a few. It should also be noted that most works which contain the concept of "indicators" in their titles are in fact applications of an index, defined as a set of aggregated or weighted parameters or indicators [20].

Other approaches to the development of indicators have been made through historical-environmental studies [26], which attempt to understand historical processes and their influence on a geographical space for a deeper understanding of how they affect each other. Thus, historicalenvironmental studies may be important for understanding past processes and their effects on the present, explaining more clearly the current configuration of the landscape and establishing well-founded bases for generating prospects at territory level [27].

In this context, the use of geographical-environmental indicators can help to improve understanding of these systems as a tool for decision-makers, ideally in a participative framework [28]. One example of this is the work of [18], who proposes 54 indicators for integrated coastal zone management grouped into legal, socioeconomic, equipment and infrastructure, tourism, and human capital. One element which facilitates the compression of work with indicators is the fact that they can be shown in graphic form using maps and even videos (e.g. [29]), providing significant support for applications such as the identification and prioritization of areas for ecological restoration, urban development, landscape planning, and educational tasks to help the population to understand human impacts on the geographical space [26].

Finally, it should be noted that spatial analysis techniques have been used in many of the applications, in particular Geographical Information Systems (GIS) [30, 31], which make it possible to integrate information generated from remote sensors, GPS, vectorial superposition, map algebra, field work, etc. Further examples may be found in [32], who used an indicator model with which they identified Drivers-Pressures-State-Impact-Responses (DPSIR) in the coastal zone of Granada (Spain) to explore the interactions and dependence of territorial dynamics in relation to the availability of water as a limiting resource. It is also possible to review applications which propose a selection for the most suitable set of indicators for integrated coastal zone management [33].

\section{Incorporation of Indicators into Planning for Coastal Zones Presenting High Natural Risk: Earthquakes and Tsunamis in Southern Chile}

In Chile, planning for coastal zones is often done without sufficient information, either in terms of quality or quantity of data, and generally with a low level of citizen participation. As a result, in some cases the legal instruments are incomplete or not integrated, as well as incapable of recognising the dynamics of the territorial system [16].

From the point of view of natural catastrophes and their historical behaviour, La Araucanía and Los Ríos Regions of southern Chile, which form part of the Arauco-Chiloé tectonic segment of the convergence line between the Nazca and South American Plates, have been shaken by five major earthquakes in the last 500 years: $1575,1633,1737,1837,1960$ [34]. Of these, it is probable that the 1575 earthquake, similar in magnitude to that of 1960 [7], generated a violent tsunami along the coast of the Araucanía and Los Ríos Regions. As in 1960, the 1575 earthquake generated coastal subsidence in the lower reaches of the Imperial and Valdivia Rivers, and at least two chronicles exist which report that the tsunami killed more than one thousand indians on the Toltén coast [7].

This history of earthquakes and tsunamis in the Arauco-Chiloé segment has recently been compared to the seismic history of the Constitución-Concepción segment, the rupture of which caused the earthquake of 27 February 2010 [7]. Surprisingly, earthquakes in the two segments display some similarities in their temporal pattern, which might be used as an indicator of a possible relation-determined by the tectonic mechanisms which control the occurrence of subduction earthquakes (Figure 1).

This context gives rise to the theory of Stress Transfer $[35,36]$. Subduction earthquakes and associated tsunamis in Chile are generated by the convergence of the Nazca and South American Plates. Because the plates do not slide smoothly over one another, there is an accumulation of tension which not only deforms the continent between one earthquake and another but also generates major earthquakes when the obstructions rupture [37]. Thus the 
Table 1. Applications of indicators with a geographical representation used in different context and in different parts of the world.

\begin{tabular}{|c|c|c|c|c|c|c|}
\hline Indicator name & Context & Type & Description & $\begin{array}{c}\text { Application } \\
\text { scale }\end{array}$ & Object & Source \\
\hline $\begin{array}{l}\text { SQI (Soil } \\
\text { Quality } \\
\text { Indicator) }\end{array}$ & Environmental & Index & $\begin{array}{l}\text {-Texture (lab. analysis) } \\
\text {-Parents materials (field observation, } \\
\text { soil maps) } \\
\text {-Rock fragment }(\%) \\
\text {-Slope gradient }(\%) \\
\text {-Drainage status (field observation, soil } \\
\text { maps) } \\
\text {-Soil depth (cm) }\end{array}$ & $\begin{array}{l}\text { Local } \\
\text { (Bustan } 3 \\
\text { area, Egypt) }\end{array}$ & $\begin{array}{l}\text { The assessment, monitoring, and mapping } \\
\text { of the areas most sensitive to } \\
\text { desertification in the Bustan } 3 \text { area, } \\
\text { Egypt. }\end{array}$ & [89] \\
\hline $\begin{array}{l}\text { Land cover and } \\
\text { landscape } \\
\text { structure }\end{array}$ & $\begin{array}{l}\text { Ecosystem } \\
\text { services }\end{array}$ & Indicator & $\begin{array}{l}\text {-Land cover type and area (ha) } \\
\text {-Cohesion and coverage of land cover } \\
\text { and landscape elements (m or ha) } \\
\text {-Number (number/ha), size (ha) and } \\
\text { spatial extent of dairy farms (ha) }\end{array}$ & $\begin{array}{l}\text { Local (Het } \\
\text { Groene Woud; } \\
\text { The } \\
\text { Netherlands }\end{array}$ & $\begin{array}{l}\text { Developing a framework for the } \\
\text { systematic selection of indicators, to } \\
\text { assess the link between land } \\
\text { management and ecosystem services } \\
\text { provision in a spatially explicit manner. }\end{array}$ & {$[90]$} \\
\hline $\begin{array}{l}\text { Emissions } \\
\text { level }\end{array}$ & $\begin{array}{l}\text { Environmental } \\
\text { health }\end{array}$ & Indicator & -tons/year & $\begin{array}{l}\text { International } \\
\text { (16 Latin } \\
\text { American } \\
\text { cities) }\end{array}$ & $\begin{array}{l}\text { Reviewing current frameworks for } \\
\text { environmental health indicators and } \\
\text { discussing the advantages and } \\
\text { limitations of various forms. }\end{array}$ & [91] \\
\hline Unemployment & $\begin{array}{l}\text { Sustainable } \\
\text { development }\end{array}$ & Indicator & $\begin{array}{l}\text {-Unemployment rate }(\% \text { by sex }) \\
\text {-People registered in employment } \\
\text { offices (number) } \\
\text {-People registered in employment } \\
\text { offices according to time of } \\
\text { registration: }>1 \text { year or } \geq 1 \text { year }(\%)\end{array}$ & $\begin{array}{l}\text { Local/ } \\
\text { Regional } \\
\text { (Algarve; } \\
\text { Portugal) }\end{array}$ & $\begin{array}{l}\text { Developing a conceptual framework for } \\
\text { common local sustainability indicators } \\
\text { within a regional context; one that is } \\
\text { supported by a participative approach and } \\
\text { allows interaction between local and } \\
\text { regional scales. }\end{array}$ & [28] \\
\hline $\begin{array}{l}\text { Benthic } \\
\text { index } \\
\text { of biotic } \\
\text { integrity }\end{array}$ & $\begin{array}{l}\text { Biotic } \\
\text { integrity }\end{array}$ & Index & $\begin{array}{l}\text {-Shannon-Wiener species diversity } \\
\text { index } \\
\text {-Total species abundance } \\
\text {-Total species biomass } \\
\text {-Abundance of pollution indicative } \\
\text { taxa (\%) } \\
\text {-Abundance of pollution sensitive } \\
\text { taxa (\%) } \\
\text {-Biomass of pollution indicative } \\
\text { taxa (\%) } \\
\text {-Biomass of pollution sensitive } \\
\text { taxa (\%) } \\
\text {-Abundance of carnivore and omnivore } \\
\text { species (\%) } \\
\text {-Abundance of deep-deposit feeders } \\
\text { (\%) } \\
\text {-Tolerance score } \\
\text {-Tanipodinae to Chironomidae percent } \\
\text { abundance ratio }\end{array}$ & $\begin{array}{l}\text { Local } \\
\text { (Mondego } \\
\text { estuary; } \\
\text { Portugal) }\end{array}$ & $\begin{array}{l}\text { This paper focuses mainly on benthic } \\
\text { community-based, biotic indices, } \\
\text { supplying a general overview of several } \\
\text { indices, premises and assumptions as well } \\
\text { as their main advantages and } \\
\text { disadvantages. }\end{array}$ & [92] \\
\hline $\begin{array}{l}\text { Disaster } \\
\text { Risk Index }\end{array}$ & $\begin{array}{l}\text { Natural } \\
\text { hazards }\end{array}$ & Index & $\begin{array}{l}\text {-Number of expected human impacts } \\
\text { (killed/year) } \\
\text {-Frequency of a given hazard } \\
\text { (event/year) } \\
\text {-Population living in a given exposed } \\
\text { area (exposed population/event) } \\
\text {-Vulnerability depending on } \\
\text { socio-politico-economical context of } \\
\text { this population (non-dimensional } \\
\text { number between } 0 \text { - } 1 \text { ) }\end{array}$ & $\begin{array}{l}\text { Global/ } \\
\text { Multiscale }\end{array}$ & $\begin{array}{l}\text { Presenting a model of factors influencing } \\
\text { levels of human losses from natural } \\
\text { hazards at the global scale, for the period } \\
1980-2000 \text {. }\end{array}$ & [93] \\
\hline $\begin{array}{l}\text { Oceanography } \\
\text { state }\end{array}$ & $\begin{array}{l}\text { Climate } \\
\text { change }\end{array}$ & Indicator & $\begin{array}{l}\text {-Temperature } \\
\text {-Salinity } \\
\text {-Mixed layer depth } \\
\text {-Stratification } \\
\text {-Heat content } \\
\text {-Sea-level elevations }\end{array}$ & $\begin{array}{l}\text { Continental } \\
\text { (Europe) }\end{array}$ & $\begin{array}{l}\text { Synthesizing the current state of } \\
\text { knowledge with regard to general and } \\
\text { region-specific impacts of climate change } \\
\text { on } 10 \text { European marine systems. }\end{array}$ & [94] \\
\hline $\begin{array}{l}\text { Urban } \\
\text { planning } \\
\text { Indicator }\end{array}$ & $\begin{array}{l}\text { Urban } \\
\text { planning }\end{array}$ & Indicator & $\begin{array}{l}\text {-Building density (footprint area of all } \\
\text { buildings/area of the land on which } \\
\text { they are located) } \\
\text {-Green space ratio (ratio of the total } \\
\text { area of all green spaces, } \\
\text { under-the-canopy, to the land) }\end{array}$ & $\begin{array}{l}\text { Urban } \\
\text { (Central } \\
\text { Beijing; } \\
\text { China) }\end{array}$ & $\begin{array}{l}\text { Simulating urban heat island effects and } \\
\text { exploring the relationship between } \\
\text { urban planning indicators and } \\
\text { climate indicators. }\end{array}$ & [95] \\
\hline
\end{tabular}


Continued

\begin{tabular}{|c|c|c|c|c|c|c|}
\hline Education & $\begin{array}{l}\text { Economic } \\
\text { growth and } \\
\text { poverty }\end{array}$ & Indicator & $\begin{array}{l}\text {-Average education of respondents } \\
\text { and partners } \\
\text {-Average education of respondents } \\
\text { (aged between } 20-30 \text { ) } \\
\text {-Maximal education of respondents } \\
\text { and partners } \\
\text {-Maximal education of respondents } \\
\text { (aged between } 20-30 \text { ) }\end{array}$ & $\begin{array}{l}\text { Country } \\
\text { (Bolivia) }\end{array}$ & $\begin{array}{l}\text { Reviewing the debate on the definition of } \\
\text { pro-poor growth and extending the } \\
\text { pro-poor growth tool-box to non-income } \\
\text { indicators. }\end{array}$ & [96] \\
\hline
\end{tabular}

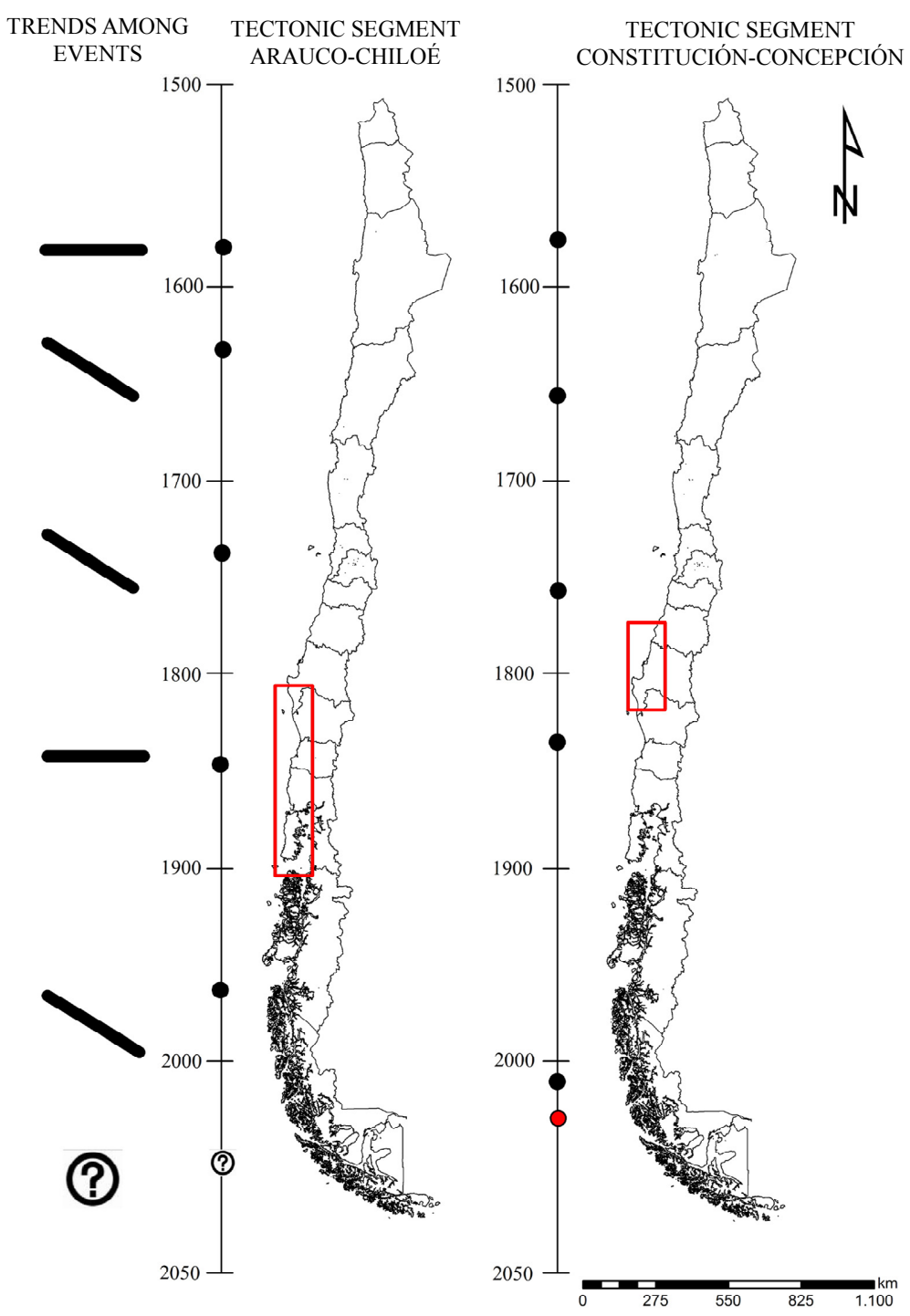

Figure 1. Comparison between the dates of major earthquakes and tsunamis in the Arauco-Chiloé and Constitución-Concepción tectonic segments. The vertical axis represents time in years AD and the black dots indicate the dates of an earthquake or tsunami. The thick black lines, horizontal or oblique, are an attempt to represent the temporal trend between the occurrences of the events in the two tectonic segments. A common temporal pattern between the earthquakes of the two segments is apparent, and raises a question with respect to the last earthquake in February 2010 (red dot). Source: own elaboration.

whole Chilean continental margin is under permanent tension. The theory proposes that as time passes, tension (or stress) accumulates. This has been demonstrated with GPS measurements showing that the South American Plate accumulates tension throughout the length of Chile
[38]; this indicator is easy to prepare and incorporate into planning and large scale risk studies.

When the Constitución-Concepción segment ruptured, it released its accumulated energy and the tension passed to the plates in the segments immediately to the north (La 
Serena-Valparaíso) and south (Arauco-Chiloé) [39,40]. In other words, those two segments are now resisting the tension which was previously resisted across the three segments, and the probability may have increased of a rupture in one of these neighbouring zones. For this reason, and given the importance of these natural phenomena for both the safety of the population and the destruction of infrastructure, long term prognosis studies need to be carried out along the country's coastal territories in order to prepare indicators which will improve our understanding of the natural system and so plan for these zones. Such studies should be oriented towards "long term prognoses", presented as the probability of occurrence in a determined period of time. The questions which a good long term prognosis should answer are "Where?", "When?" and "How big?" [41].

Nevertheless, considering that the major subduction earthquakes affecting Chile are very infrequent, it is difficult to answer based only on a study of historical records, which are generally too short to represent the geological scale which governs the occurrence of major events. In this regard, it is known that gigantic earthquakes and tsunamis, like that of 1960, affect the Arauco-Chiloé segment every 300 years or more. Since the written history of the regions which include this segment covers no more than 500 years, it records no more than one complete cycle, meaning that history is not able to answer the questions necessary for a good prognosis [7].

It is therefore necessary to prepare additional indicators based on paleo-seismology, to overcome the barrier imposed by written history and generate long term information, on a scale of millennia, to help answer the questions proposed above [42]. In general, paleo-seismological methods look for the natural traces left on the coast by past events. Thus recognition of the evidence at a certain place helps to answer the question "Where?"; by dating the events at that place we can try to answer "When?"; and by studying the geographical extent of the evidence we can attempt to answer "How big?"

\section{Spatial Decision Support Systems for Planning and Integrated Management of Coastal Zones}

Decision support systems (DSS) were developed to deal with the complexity and uncertainty of the possibilities which must often be faced in a decision-making process $[43,44]$. For decades, scientists and researchers from a wide variety of disciplines, such as economics, psychology, computer science, etc., have focused their interest on understanding behaviour and the methodological challenges of implementing decision support models [45, 46]. In general terms the most widely published models for DSS include hierarchic analytical processes, decision matrices and trees, multi-criterion and multi-objective models, prediction and simulation models, optimization, and many more [47-51].

However, it must always be borne in mind that DSS do not take decisions unaided: they are only a support tool, and the results must therefore never be considered literally, but rather as a reference [52]. In this context, the concept of "spatial decision support systems (SDSS)" has recently been developed, generating increasing interest. Its many applications are based on current progress in technology, principally computer systems. These allow large volumes of data to be handled simultaneously, significantly facilitating the tasks of modelling and analysis. SDSS, unlike DSS, support decision-making processes where the principal interest is focused on the spatial component [53], as in problems of environmental assessment and territorial planning, etc. (e.g. biodiversity conservation [54]; agricultural potential [55], urban development [56] and spatial planning [57]).

In this sense, and considering the current demands placed on territorial planning, the conceptual framework of SDSS offers a perspective and a set of tools which allow good structuring of decision-making processes, integrating the intrinsic complexity of territorial systems, the various components of landscape, the view-points of the stakeholders involved, the judgement of experts, and tools for geospatial analysis and modelling. All this focused on the creation of a more transparent and participative process between the interested parties $[3,58,59]$.

These procedures facilitate the exploration of alternatives through the generation of different scenarios, starting with the initial question "What would happen if...?" [54]. Thus, the aim of implementing an SDSS would then be to provide a framework for geo-technological integration which takes into account the analytical capacities of spatial modelling, database management tools, applications for graphic viewing of the territory, incorporation of field data, etc. [43]. All these components can be satisfactorily implemented using geo-information technology, in particular Geographical Information Systems (GIS) [60].

According to [61], a GIS is defined as a tool for digital management of geographical information and its associated databases, and can be seen as a support system which integrates spatially referenced data in a decisionmaking problem. Thus in recent years the importance has been shown of these techniques and tools, and of the interdisciplinary and multidimensional focuses found at the heart of the development of SDSS, especially in environmental assessment or conservation and territorial planning (e.g. [62-64]).

The appearance of web portals for integration and discussion of knowledge in the field, such as the Spatial Decision Support Consortium 
(http://www.spatial.redlands.edu/sds/) or the Eastern Decision Support Consortium

(http://environment.yale.edu/gisf/programs/eastern-decisi on-support-consortium/), has lent great support to the development of these tools. Furthermore, a large number of scientific works have been published on this subject, with conceptual modelling applications for validating variables, identifying criteria, and preparing status indicators and work on WebGIS platforms [65-70]; and also for developing spatial indicators, value functions and spatial support systems in various environments [71-75].

\section{Coastal Zone Planning and Management in Chile: The Reality and the Challenges}

In Chile, the term coastal zone is a legal concept, defined in the National Policy for the Use of the Coastal Zone of the Shores of the Republic. It includes publicly owned shoreline, beaches, bays, gulfs, narrows and channels and the territorial maritime waters of the Republic, which are subject to the control, inspection and supervision of the Ministry of National Defence and the current Undersecretary for the Armed Forces. In specific terms, the institution basically responsible for the planning and management of the coastal zone is the National Commission for the Use of the Coastal Zone (Comisión Nacional de Uso del Borde Costero-CNUBC), one of the principal functions of which is to propose zoning of the various spaces which make up the Coastal Zone of the Chilean shoreline. The formation of this commission opened a new phase for Chile in the planning and management of its coastal and maritime zones, through a territorial ordering process which incorporates the spatial expression of economic, social, cultural and environmental policies, based on the sustainable administration of resources.

Although this policy is nearly 20 years old, significant progress during the period 2009-2012 led to one of its greatest achievements: the Coastal Zoning Programme (Programa de Zonificación del Borde Costero-PZBC). The object of this scheme is to incorporate Integrated Coastal Zone Management (ICZM) into the planning and ordering of the coastal zone in Chile

(http://bordecostero.ssffaa.cl), defined as a dynamic, continuous, repetitive process designed to promote the sustainable management of coastal zones [76].

The object of using the ICZM process is to develop a strategic plan for the coastal zone through assignation of the natural resources present in the territory, based on an exhaustive assessment of its environmental and socioeconomic components. In this context, the object of zoning the spaces which make up the Coastal Zone is to define the territory included and to establish its many uses, expressed in preferred uses and recorded cartographically, identifying the geographical limits, general zoning and the conditions and restrictions for administration in con- formance with the provisions of the Law.

It should be noted that the policy for the use of the coastal zone tends towards: 1) proper consideration of the geographical situation of each sector or area of the shoreline; 2) development of the resources and wealth of the different sectors; 3) protection and conservation of the maritime, terrestrial and aerial environment; 4) proper compatibilisation of the many activities carried out, or which could be carried out, in the Coastal Zone; 5) enabling and guiding the balanced development of the different activities from a national perspective, but following regional, local and sectorial interests; and 6) contributing to the identification of future perspectives and projections of each of the activities to be carried out in coastal territorial zones, considering that the coast is a limited resource. This legal framework is complemented by the competence of other institutions with attributions over the use of the shoreline, such as the Under-secretary of Fishing, the Environment Ministry (ex National Environment Commission [CONAMA]), the National Assets Ministry and the General Directorate of Maritime Territory and the Merchant Marine.

Although a centralizing trend has always existed in Chile, efforts at decentralisation have been made by the State recently [77]; nevertheless, coordination between public institutions has not yet been achieved. Some authors suggest that greater cooperation between Ministries (National Defence, National Assets, Housing and Urban Development, Economy, etc.) and the other territorial levels of Administration (Regions and Municipalities) would lead to a considerable improvement in the planning and management of these zones [16,78].

In mainland Chile, planning of coastal zones has been dependent on the application of laws such as the General Law of Urban Development and Construction (LGUC) and the General Ordinance of Urban Development and Construction (OGUC). The principal instruments are the Communal [Municipal] Regulatory Plans (PRC), which act as norms and bring together the guidelines and standards of higher levels of government, such as the Intercommunal Regulatory Plan [79-81]. However these "instruments of a normative character (IPT) are not properly suited to the nature and speed of the transformations which are occurring in coastal zones, in particular associated with housing development and industrial occupation, nor to the need to protect fragile zones based on more sensitive criteria than have been applied to date" [16].

Furthermore, it is not easy to define coastal zones in territorial terms, despite the great interest of such a definition for government agencies responsible for coastal planning and administration, and even for businessmen, workers and residents. This is due principally to the fact that the limits may be set from either bio-physical or po- 
litical viewpoints, often creating ambiguity as to their function [82]. However, in recent years interest in coastal management has moved from a focus on an eminently sectorial understanding towards a more holistic and integrated plan of its components [12], which in Chile is starting to be proposed from the angle of Strategic Environmental Assessment (SEA). This supports proposals for multifactorial analyses to help in decision-making at different levels among public figures and stakeholders as a sustainable alternative for territorial planning and management. The SEA law explicitly states that general normative policies and plans, and substantial modifications to them, which have an impact on the environment or its sustainability, should be subjected to SEA, imparting an unconditional character to all instruments for territorial planning proposed in the future, as well as those which replace or systematise them.

Internationally, the development of planning and management strategies has been marked by participative focuses, needs for multiple use, and conflicts of use. Examples of these are the Strategies for Integrated Management of Shore Areas or coastal zones in Spain [83], the Landscape Planning Focus [73,84-86] and the IberoAmerican Coastal Zone Management Network-IBER MAR (http://www.gestioncostera.es/ibermar/).

\section{Final Comments}

There is a need to develop geographical-environmental based territorial planning, which may be understood to be the broadest, most integrative level of planning. Under this approach it is possible to consider the ecological condition of the territorial system, together with its social, cultural and economic dynamics, in a spatial context. This approach is aimed at generating technical and scientific information, aligned with the political requirements necessary for decision-making in planning and the administrative, legal and social instruments needed to ensure application [87,27].

Likewise a parallel is established with the broad concept of territorial ordering, conceived as the spatial expression of a society's economic, social, cultural and ecological policies. Territorial ordering is considered as a scientific discipline, an administrative technique and a policy-conceived as global interdisciplinary action with the central objective of balanced development of different regions and the physical organization of space under a guiding concept $[15,27]$. This process is based on three fundamental principles: a) maximising the use of the territory's potentials and resources (supply), b) minimising the degradation and impacts of the socio-economic activities carried on (demand), and c) maintaining the ecological equilibrium, i.e. the spatial configuration (structure), functioning, dynamic and evolution of the natural systems.
These integrating, systemic focuses require the availability of geographical-environmental indicators, both from the point of view of the fragility and singularity of coastal zones and from that of their social, economic and natural risks dynamics. Chile does not have yet the tools to generate support for the development of effective, informed decision-making processes for sustainable development, with the inclusion of natural risk factors, ecological-environmental values, the economic-productive dimension and socio-cultural values in territorial planning instruments. These elements would allow promotion of integrated coastal zone management, with the long term object of balancing the benefits of economic development with use of the Coastal Zone by human beings [88].

At the same time, the seismic situation of Chile and recent destructive natural events offer at least two reasons for giving urgent consideration to this issue in characterising coastal environments for territorial planning. On the one hand, from a historical perspective a close relation in time is observed between seismic events in the Constitución-Concepción segment and those in the Arauco-Chiloé segment. On the other, based on tectonic Stress Transfer theory, it is to be expected that the next major event will occur in the neighbouring segments to the point of the rupture in 2010, namely Valparaíso-La Serena and/or Arauco-Chiloé.

Thus the incorporation of paleoseismological indicators into coastal planning and studies of natural hazards would allow better knowledge of the spatial and temporal behaviour of destructive natural events, specifically tsunamis. This knowledge could help to mitigate their effects on the population and infrastructure.

Finally, it should be noted that Chile's current regulatory framework for territorial management and planning suffers from a series of limitations, and that there is a need to generate coastal management tools suited to the country's complexity, dynamic, and existing levels of human intervention. This implies facilitating dialogue among stakeholders, the availability of strategic information, the existence of tools for assessment and planning, the definition and achievement of environmental sustainability objectives for development, and especially the generation of support systems to facilitate decisionmaking in contexts where spatially explicit attributes are of great importance.

\section{Acknowledgements}

The authors are grateful for the support provided by Comisión Nacional de Investigación Científica y Tecnológica (CONICYT), through FONDECYT project 1110 798: "Determinación de indicadores geográficoambientales y de riesgo natural en el paisaje de La Araucanía y 
Los Ríos: Herramientas de soporte decisional para la planificación y gestión territorial en sistemas costeros". Our thanks also to researcher Susanne Frank for her valuable comments and Fabian Argandoña for his help in editing the text.

\section{REFERENCES}

[1] R. Forman, "Some General Principles of Landscape Ecology and Regional Ecology," Landscape Ecology, Vol. 10, No. 3, 1995, pp. 133-142. doi:10.1007/BF00133027

[2] J. Iverson, "Landscape as Medium and Method for Synthesis in Urban Ecological Design," Landscape and Urban Planning, Vol. 106, No. 1, 2012, pp. 221-229.

[3] D. Geneletti, "Formalising Expert Opinion through MultiAttribute Value Functions: An Application in Landscape Ecology," Journal of Environmental Management, Vol. 76, No. 3, 2005, pp. 255-262. doi:10.1016/j.jenvman.2005.01.025

[4] E. Andersson and Ö. Bodin, "Practical Tool for Landscape Planning? An Empirical Investigation of Network Based Models of Habitat Fragmentation," Ecography, Vol. 32, No. 2, 2009, pp. 123-132. doi:10.1111/j.1600-0587.2008.05435.x

[5] R. Mc Vinish and P. K. Pollet, "Interaction between Habitat Quality and an Allee-Like Effect in Metapopulations," Ecological Modelling, Vol. 249, 2013, pp. 84-89. doi:10.1016/j.ecolmodel.2012.07.001

[6] L. Bertolo, G. Lima and R. Santos, "Identifying Change Trajectories and Evolutive Phases on Coastal Landscapes. Case Study: São Sebastião Island, Brazil," Landscape and Urban Planning, Vol. 106, No. 1, 2012, pp. 115-123. doi:10.1016/j.landurbplan.2012.02.009

[7] M. Cisternas, B. Atwanter, F. Torrejón, Y. Sawai, G. Machuca, M. Lagos, A. Eipert, C. Youlton, I. Salgado, T. Kamataki, M. Shishikura, C. Rajendran, J. Malik, Y. Rizal and M. Husni, "Predecessors of the Giant 1960 Chile Earthquake," Nature, Vol. 437, No. 7057, 2005, pp. 404407. doi:10.1038/nature03943

[8] V. K. Gahalaut and J. K. Catherine, "Rupture Characteristics of 28 March 2005 Sumatra Earthquake from GPS Measurements and Its Implication for Tsunami Generation," Earth and Planetary Science Letters, Vol. 249, No. 1-2, 2006, pp. 39-46. doi:10.1016/j.eps1.2006.07.015

[9] D. Melnick, M. Cisternas, M. Moreno and R. Norambuena, "Estimating Coseismic Coastal Uplift with an Intertidal Mussel: Calibration for the 2010 Maule Chile Earthquake ( $\mathrm{Mw}=8.8)$," Quaternary Science Reviews, Vol. 42, 2012, pp. 29-42. doi:10.1016/j.quascirev.2012.03.012

[10] C. Davis, V. Keilis-Borok, V. Kossobokov and A. Soloviev, "Advance Prediction of the March 11, 2011 Great East Japan Earthquake: A Missed Opportunity for Disaster Preparedness," International Journal of Disaster Risk Reduction, Vol. 1, 2012, pp. 17-32. doi:10.1016/j.ijdrr.2012.03.001

[11] D. Masalu, "Coastal Data and Information Management for Integrated Coastal Management: The Role of IODE,"
Marine Policy, Vol. 32, No. 6, 2008, pp. 544-550. doi:10.1016/j.marpol.2007.10.003

[12] I. Divien and S. Ramachandran, "The Role of Spatial Planning in Coastal Management-A Case Study of Tuticorin Coast (India)," Land Use Policy, Vol. 27, No. 2, 2010, pp. 518-534. doi:10.1016/j.landusepol.2009.07.007

[13] M. E, Portman, L. S. Esteves, X. Q. Le and A. Z. Khan, "Improving Integration for Integrated Coastal Zone Management: An Eight Country Study," Science of the Total Environmental, Vol. 439, 2012, pp. 194-201. doi:10.1016/j.scitotenv.2012.09.016

[14] S. Pourebrahim, M. Hadipour and M. Bin Mokhtar, "Integration of Spatial Suitability Analysis for Land Use Planning in Coastal Areas; Case of Kuala Langat District, Selangor, Malaysia," Landscape and Urban Planning, Vol. 101, No. 1, 2011, pp. 84-97. doi:10.1016/j.landurbplan.2011.01.007

[15] J. Barragán, “Ordenación, Planificación y Gestión del Espacio Litoral," Oikos-Tau, Barcelona, 1994.

[16] B. Andrade, F. Arenas and M. Lagos, "Incorporación de Criterios de Fragilidad Ambiental y Riesgo en la Planificación Territorial de la Costa de Chile Central," Revista de Geografía Norte Grande, No. 45, 2010, pp. 5-20.

[17] Y. Basraoui, A. Chafi, Y. Zarhloule and S. Demnati, “An Integrated Coastal Zone Management Initiative for Sensitive Coastal Wetland on Either Sides of the Moulouya Estuary in Morocco," Procedia Social and Behavioral Sciences, Vol. 19, 2011, pp. 520-525.

doi:10.1016/j.sbspro.2011.05.164

[18] A. Diedrich, J. Tintoré and F. Navine, "Balancing Science and Society through Establishing Indicators for Integrated Coastal Zone Management in the Balearic Islands," Marine Policy, Vol. 34, No. 4, 2010, pp. 772-781. doi:10.1016/j.marpol.2010.01.017

[19] A. H. Pickaver, C. Gilbert and F. Breton, "An Indicator Set to Measure the Progress in the Implementation of Integrated Coastal Zone Management in Europe," Ocean \& Coastal Management, Vol. 47, 2004, No. 9-10, pp. 449462.

[20] Organisation for Economic Co-Operation and Development (OECD), "Environmental indicators Development, Measurement and Use," 2003.

http://www.oecd.org/environment/indicators-modelling-o utlooks/24993546.pdf

[21] D. Niemeijer and R. S. de Groot, "A Conceptual Framework for Selecting Environmental Indicator Sets," Ecological Indicators, Vol. 8, No. 1, 2008, pp. 14-25. doi:10.1016/j.ecolind.2006.11.012

[22] H. Helbron, M. Schmidt, J. Glasson and N. Downes, "Indicators for Strategic Environmental Assessment in Regional Land Use Planning to Assess Conflicts with Adaptation to Global Climate Change," Ecological Indicators, Vol. 11, No. 1, 2011, pp. 90-95. doi:10.1016/j.ecolind.2009.06.016

[23] E. Rametsteiner, H. Pülzl, J. Alkan-Olsson and P. Frederiksen, "Sustainability Indicator Development-Science or Political Negotiation?” Ecological Indicators, Vol. 11, No. 1, 2011, pp. 61-70. doi:10.1016/j.ecolind.2009.06.009 
[24] I. Androulidakis and I. Karakassis, "Evaluation of the EIA System Performance in Greece, Using Quality Indicators," Environmental Impact Assessment Review, Vol. 26, No. 3, 2006, pp. 242-256.

doi:10.1016/j.eiar.2005.10.001

[25] O. Myhre, K. Fjellheim, H. Ringnes and T. Reistad, "Development of Environmental Performance Indicators Supported by an Environmental Information System: Application to the Norwegian Defence Sector," Ecological Indicators, Vol. 29, 2013, pp. 293-306. doi:10.1016/i.ecolind.2013.01.005

[26] R. Tiner, "Remotely-Sensed Indicators for Monitoring the General Condition of 'Natural Habitat' in Watersheds: An Application for Delaware's Nanticoke River Watershed," Ecological Indicators, Vol. 4, No. 4, 2004, pp. 227-243. doi:10.1016/j.ecolind.2004.04.002

[27] D. Gómez, “Ordenación Territorial," 2nd Edition, Ediciones Mundi-Prensa, Madrid, 2007.

[28] A. Mascarenhas, P. Coelho, E. Subtil and T. B. Ramos, "The Role of Common Local Indicators in Regional Sustainability Assessment," Ecological Indicators, Vol. 10, No. 3, 2010, pp. 646-656.

doi:10.1016/j.ecolind.2009.11.003

[29] M. Davidson, M. Van Koningsveld, A. De Kruif, J. Rawson, R. Holman, A. Lamberti, R. Medina, A. Kroon and S. Aarninkhof, "The CoastView Project: Developing VideoDerived Coastal State Indicators in Support of Coastal Zone Management," Coastal Engineering, Vol. 54, No. 6-7, 2007, pp. 463-475.

doi:10.1016/j.coastaleng.2007.01.007

[30] J. M. De Paz, J. Sánchez and F. Visconti, "Combined Use of GIS and Environmental Indicators for Assessment of Chemical, Physical and Biological Soil Degradation in a Spanish Mediterranean Region," Journal of Environmental Management, Vol. 79, No. 2, 2006, pp. 150-162. doi:10.1016/j.jenvman.2005.06.002

[31] C. Rojas, J. Pino and E. Jaque, "Strategic Environmental Assessment in Latin America: A Methodological Proposal for Urban Planning in the Metropolitan Area of Concepción (Chile)," Land Use Policy, Vol. 30, No. 1, 2013, pp. 519-527. doi:10.1016/j.landusepol.2012.04.018

[32] L. M. Valenzuela and A. Matarán, "Environmental Indicators to Evaluate Spatial and Water Planning in the Coast of Granada (Spain)," Land Use Policy, Vol. 25, No. 1, 2008, pp. 95-105. doi:10.1016/j.landusepol.2007.03.002

[33] M. Sanò and R. Medina, "A Systems Approach to Identify Sets of Indicators: Applications to Coastal Management," Ecological Indicators, Vol. 23, 2012, pp. 588-596. doi:10.1016/j.ecolind.2012.04.016

[34] C. Lomnitz, "Major Earthquakes and Tsunamis in Chile during the Period 1535 to 1955 ," Geologische Rundsch, Vol. 59, No. 3, 1970, pp. 938-960. doi:10.1007/BF02042278

[35] R. Dmowska, J. Rice, L. Lovison and D. Josell, "Stress Transfer and Seismic Phenomena in Coupled Subduction Zones during the Earthquake Cycle," Journal of Geophysical Research, Vol. 93, No. B7, 1988, pp. 7869-7884. doi:10.1029/JB093iB07p07869
[36] R. Stein, "The Role of Stress Transfer in Earthquake Occurrence," Nature, Vol. 402, No. 6762, 1999, pp. 605-609. doi: $10.1038 / 45144$

[37] B. Atwater, M. Cisternas, J. Bourgeois, W. Dudley, J. Hendley and P. Stauffer, "Sobreviviendo a un Tsunami: Lecciones de Chile, Hawai y Japón,” 2009. http://pubs.usgs.gov/circ/c1218/c1218.pdf

[38] M. Moreno, J. Bolte, J. Klotz and D. Melnick, "Impact of Megathrust Geometry on Inversion of Coseismic Slip from Geodetic Data: Application to the 1960 Chile Earthquake," Geophysical Research Letters, Vol. 36, No. 16, 2009. doi:10.1029/2009GL039276

[39] A. Socquet, M. Bejar, C. Vigny, M. Doin, G. Ducret, D. Carrizo, M. Metois and G. Peltzer, "Modelling the Source of the Maule Mw 8.8 Earthquake and Early after Slip Using GPS and InSAR Data," Proceedings of the AGUChapman Conference on Giant Earthquakes and Their Tsunamis, Valparaiso, Viña del Mar, and Valdivia, 16-24 May 2010, pp. 48-49.

[40] C. Vigny, J. Socquet, J. Campos, D. Carrizo, J. C. Ruegg, M. Métois, S. Morvan and C. Aranda, "The Maule Mw 8.8 Earthquake Monitored by Continuous and Survey Mode GPS," Proceedings of the AGU-Chapman Conference, Giant Earthquakes and Their Tsunamis, ValparaisoViña del Mar, 16-24 May 2010, pp. 51-52.

[41] K. Satake and F. Atwater, "Long-Term Perspectives on Giant Earthquakes and Tsunamis at Subduction Zones," Annual Review of Earth and Planetary Sciences, Vol. 35 , 2007, pp. 349-374.

doi:10.1146/annurev.earth.35.031306.140302

[42] K. Goto, C. Chagué-Goff, S. Fujino, J. Goff, B. Jaffe, Y. Nishimura, B. Richmond, D. Sugawara, W. Szczucinski, D. R. Yappin, R. C. Witter and E. Yulianto, "New Insights of Tsunami Hazard from the 2011 Tohoku-Oki Event," Marine Geology, Vol. 290, No. 1-4, 2011, pp. 4650. doi:10.1016/j.margeo.2011.10.004

[43] M. Matthies, C. Giupponi and B. Ostendorf, "Environmental Decision Support Systems: Current Issues, Methods and Tools," Environmental Modelling \& Software, Vol. 22, No. 2, 2007, pp. 123-127. doi:10.1016/j.envsoft.2005.09.005

[44] A. Schmolke, P. Thorbek, D. Deangelis and V. Grimm, "Ecological Models Supporting Environmental Decision Making: A Strategy for the Future," Trends in Ecology \& Evolution, Vol. 25, No. 8, 2010, pp. 479-486. doi:10.1016/j.tree.2010.05.001

[45] T. L. Saaty, "The Analytic Hierarchy Process," 2nd Edition, McGraw Hill International, New York, 1980.

[46] I. Askira-Gelman, "Setting Priorities for Data Accuracy Improvements in Satisficing Decision-Making Scenarios: A Guiding Theory," Decision Support Systems, Vol. 48, No. 4, 2010, pp. 507-520. doi:10.1016/j.dss.2009.11.001

[47] D. Lam, L. Leon, S. Hamilton, N. Crookshank, D. Bonin and D. Swayne, "Multi-Model Integration in a Decision Support System: A Technical User Interface Approach for Watershed and Lake Management Scenarios," Environmental Modelling \& Software, Vol. 19, No. 3, 2004, pp. 317-324. doi:10.1016/S1364-8152(03)00156-7

[48] C. Gomes da Silva, J. Figueira, J. Lisboa and S. Barman, 
"An Interactive Decision Support System for an Aggregate Production Planning Model Based on Multiple Criteria Mixed Integer Linear Programming," Omega, Vol. 34, No. 2, 2006, pp. 167-177.

doi:10.1016/j.omega.2004.08.007

[49] D. Geneletti and I. van Duren, "Protected Area Zoning for Conservation and Use: A Combination of Spatial Multicriteria and Multiobjective Evaluation," Landscape and Urban Planning, Vol. 85, No. 2, 2008, pp. 97-110. doi:10.1016/j.landurbplan.2007.10.004

[50] P. Borges, R. Fragoso, J. Garcia-Gonzalo, J. Borges, S. Marques and M. Lucas, "Assessing Impacts of Common Agricultural Policy changes on Regional Land Use Patterns with a Decision Support System: An Application in Southern Portugal," Forest Policy and Economics, Vol. 12, No. 2, 2010, pp. 111-120. doi:10.1016/j.forpol.2009.09.002

[51] M. Bottero, E. Comino, M. Duriavig, V. Ferretti and S. Pomarico, "The Application of a Multicriteria Spatial Decision Support System (MCSDSS) for the Assessment of Biodiversity Conservation in the Province of Varese (Italy)," Land Use Policy, Vol. 30, No. 1, 2013, pp. 730-738. doi:10.1016/j.landusepol.2012.05.015

[52] F. Bunnell and M. Boyland, "Decision-Support Systems: It's the Question Not the Model," Journal for Nature Conservation, Vol. 10, No. 4, 2003, pp. 269-279. doi:10.1078/1617-1381-00027

[53] O. Uran and R. Janssen, "Why Are Spatial Decision Support Systems Not Used? Some Experiences from the Netherlands," Computers, Environment and Urban Systems, Vol. 27, No. 6, 2003, pp. 511-526. doi:10.1016/S0198-9715(02)00064-9

[54] D. Larson and R. Sengupta, "A Spatial Decision Support System to Identify Species-Specific Critical Habitats Based on Size and Accessibility Using USGAP Data," Environmental Modelling \& Software, Vol. 19, No. 1, 2004, pp. 7-18. doi:10.1016/S1364-8152(03)00098-7

[55] K. Wenkel, M. Berg, W. Mirschel, R. Wieland, C. Nendel and B. Köstner, "LandCaRe DSS-An Interactive Decision Support System for Climate Change Impact Assessment and the Analysis of Potential Agricultural Land Use Adaptation Strategies," Journal of Environmental Management, 2013.

[56] A. González, A. Donnelly, M. Jones, N. Chrysoulakis and M. Lopes, "A Decision-Support System for Sustainable Urban Metabolism in Europe," Environmental Impact Assessment Review, Vol. 38, 2013, pp. 109-119. doi:10.1016/j.eiar.2012.06.007

[57] G. Arciniegas and R. Janssen, "Spatial Decision Support for Collaborative Land Use Planning Workshops," Landscape and Urban Planning, Vol. 107, No. 3, 2012, pp. 332-342. doi:10.1016/j.landurbplan.2012.06.004

[58] D. Geneletti, “A GIS-Based Decision Support System to Identify Nature Conservation Priorities in an Alpine Valley," Land Use Policy, Vol. 21, No. 2, 2004, pp. 149-160. doi:10.1016/j.landusepol.2003.09.005

[59] I. Sikder, "Knowledge-Based Spatial Decision Support Systems: An Assessment of Environmental Adaptability of Crops," Expert Systems with Applications, Vol. 36, No.
3, 2009, pp. 5341-5347.

[60] R. Denzer, "Generic Integration of Environmental Decision Support Systems - State-of-the-Art," Environmental Modelling \& Software, Vol. 20, No. 10, 2005, pp. 12171223. doi:10.1016/j.envsoft.2004.09.004

[61] C. Tiba, A. L. B. Candeias, N. Fraidenraich, E. M. de S. Barbosa, P. B de Carvalho Neto and J. B. de Melo Filho, "A GIS-Based Decision Support Tool for Renewable Energy Management and Planning in Semi-Arid Rural Environments of Northeast of Brazil," Renewable Energy, Vol. 35, No. 12, 2010, pp. 2921-2932.

doi:10.1016/j.renene.2010.05.009

[62] D. Demetriou, J. Stillwell and L. See, "Land Consolidation in Cyprus: Why Is an Integrated Planning and Decision Support System required?" Land Use Policy, Vol. 29, No. 1, 2012, pp. 131-142. doi:10.1016/j.landusepol.2011.05.012

[63] K. Eldrandaly, "A GEP-Based Spatial Decision Support System for Multisite Land Use Allocation," Applied Soft Computing, Vol. 10, No. 3, 2010, pp. 694-702. doi:10.1016/j.asoc.2009.07.014

[64] D. Geneletti, "Environmental Assessment of Spatial Plan Policies through Land Use Scenarios A Study in a FastDeveloping Town in Rural Mozambique," Environmental Impact Assessment Review, Vol. 32, No. 1, 2012, pp. 1-10. doi:10.1016/j.eiar.2011.01.015

[65] L. Delgado, V. Marín, P. Bachmann and M. Torres-Gomez, "Conceptual Models for Ecosystem Management through the Participation of Local Social Actors: The Río Cruces Wetland Conflict," Ecology and Society, Vol. 14, No. 1, 2009, p. 50.

[66] V. H. Marín and L. E. Delgado, "A Phes-System Approach to Coastal Zone Management," In: R. Neves, J. W. Baretta and M. Mateus, Eds., Perspectives on Integrated Coastal Zone Management in South America, IST Press, Lisboa, 2008, pp. 61-70.

[67] R. Margoluis, C. Stem, N. Salafsky and M. Brown, "Using Conceptual Models as a Planning and Evaluation Tool in Conservation," Evaluation and Program Planning, Vol. 32, No. 2, 2009, pp. 138-147. doi:10.1016/j.evalprogplan.2008.09.007

[68] A. Cataldo and A. Rinaldo, "An Ontological Approach to Represent Knowledge in Territorial Planning Science. Computers," Environment and Urban Systems, Vol. 34, No. 2, 2010, pp. 117-132. doi:10.1016/j.compenvurbsys.2009.09.004

[69] R. Scolozzi and D. Geneletti, "A Multi-Scale Qualitative Approach to Assess the Impact of Urbanization on Natural Habitats and Their Connectivity," Environmental Impact Assessment Review, Vol. 36, 2012, pp. 9-22. doi:10.1016/j.eiar.2012.03.001

[70] B. Thiebes, R. Bell, T. Glade, S. Jäger, M. Anderson and L. Holcombe, "A WebGIS Decision-Support System for Slope Stability Based on Limit-Equilibrium Modeling," Engineering Geology, Vol. 158, 2013, pp. 109-118. doi:10.1016/j.enggeo.2013.03.004

[71] R. Forman and S. Collinge, "Nature Conserved in Changing Landscapes with and without Spatial Planning," Landscape and Urban Planning, Vol. 37, No. 1-2, 1997, 
pp. 129-135. doi:10.1016/S0169-2046(96)00378-7

[72] A. Bodini, A. Ricci and P. Viaroli, "A Multimethodological Approach for the Sustainable Management of Perifluvial Wetlands of the Po River (Italy)," Environmental Management, Vol. 26, No. 1, 2000, pp. 59-72. doi:10.1007/s002670010071

[73] J. Kangas, R. Store and A. Kangas, "Socioecological Landscape Planning Approach and Multicriteria Acceptability Analysis in Multiple-Purpose Forest Management," Forest Policy and Economics, Vol. 7, No. 4, 2005, pp. 603-614. doi:10.1016/j.forpol.2003.12.001

[74] M. C. Ruiz, E. Romero, M. A. Pérez and I. Fernández, "Development and Application of a Multi-Criteria Spatial Decision Support System for Planning Sustainable Industrial Areas in Northern Spain," Automation in Construction, Vol. 22, 2012, pp. 320-333. doi:10.1016/j.autcon.2011.09.009

[75] P. V. Gorsevski, S. Cathcart, G. Mirzaei, M. Jamali, X. Ye and E. Gomezdelcampo, "A Group-Based Spatial Decision Support System for Wind Farm Site Selection in Northwest Ohio," Energy Policy, Vol. 55, 2013, pp. 374385.doi:10.1016/j.enpol.2012.12.013

[76] European Commission, "Towards a European Integrated Coastal Zone Management (ICZM) Strategy. General Principles and Policy Options," 1999.

http://ec.europa.eu/environment/iczm/pdf/vol1.pdf

[77] J. Barragán, "El Manejo Integrado Costero en Cuba: Propuestas Para Avanzar Hacia una Implementación Exitosa. Manejo Costero Integrado y Política Pública en Iberoamérica: Propuestas Para la Acción,” In: J. A. Cabrera Hernández, Ed., El Manejo Integrado Costero en Cuba: Propuestas Para Avanzar Hacia una Implementación Exitosa, Cádiz, 2011, pp. 71-91.

[78] C. Castro and E. Morales, "La Zona Costera. Medio Natural y Ordenación Integrada," Instituto de Geografía (PUC), Serie GEOlibros, Santiago, 2006.

[79] S. Baeriswyl, "Nuevos Desafíos Urbanos y Nuevas Herramientas de Planificación," Revista Urbano, Vol. 9, No. 13, 2006, pp. 44-47.

[80] M. Sanhueza and F. Peña-Cortés, "Planes Reguladores Comunales en la Región del Biobio: Estado y Situación Actual," Revista Urbano, Vol. 13, No. 22, 2010, pp. 3242.

[81] G. Gutiérrez and F. Peña-Cortés, "Estado y Situación Actual de los Planes Reguladores Comunales en la Región de la Araucanía (Chile)," DAAPGE, Vol. 11, No. 16, 2011, pp. 97-119.

[82] J. Duxbury and S. Dickinson, "Principles for Sustainable Governance of the Coastal Zone: In the Context of Coastal Disasters," Ecological Economics, Vol. 63, No. 2-3, 2007, pp. 319-330. doi:10.1016/j.ecolecon.2007.01.016

[83] J. Barragán, "Coastal Management and Public Policy in Spain," Ocean \& Coastal Management, Vol. 53, No, 5-6, 2010, pp. 209-217. doi:10.1016/j.ocecoaman.2010.04.006

[84] V. Dale, S. Brown, R. Haeuber, N. Hobbs and N. Huntly, "Ecological Principles and Guidelines for Managing the Use of Land," Ecological Applications, Vol. 10, No. 3, 2000, pp. 639-670.
[85] B. Arheimer, G. Torstensson and H. Wittgren, "Lanscape Planning to Reduce Coastal Eutrophication: Agricultural Practices and Constructed Wetlands," Landscape and Urban Planning, Vol. 67, No. 1-4, 2004, pp. 205-215. doi:10.1016/S0169-2046(03)00040-9

[86] H. Klug, "An Integrated Holistic Transdisciplinary Landscape Planning Concept after the Leitbild Approach," Ecological Indicators, Vol. 23, 2012, pp. 616-626. doi:10.1016/j.ecolind.2012.05.019

[87] E. Salinas, "Planificación Ambiental y Ordenamiento Geoecológico," Proceedings of the II Taller Internacional sobre Ordenamiento Geoecológico de los Paisajes, La Habana, Diciembre, 1997, pp. 7-11.

[88] J. Barragán, “Towards Integrated Coastal Zone Management in Chile," Coastal Management, Vol. 33, No. 1, 2005, pp. 1-24. doi:10.1080/08920750590883141

[89] N. Bakr, D. Weindorf, M. Bahnassy and M. El-Badawi, "Multi-Temporal Assessment of Land Sensitivity to Desertification in a Fragile Agro-Ecosystem: Environmental Indicators," Ecological Indicators, Vol. 15, No. 1, 2012, pp. 271-280. doi:10.1016/j.ecolind.2011.09.034

[90] A. P. E. van Oudenhoven, K. Petz, R. Alkemade, L. Hein and R. S. de Groot, "Framework for Systematic Indicator Selection to Assess Effects of Land Management on Ecosystem Services," Ecological Indicators, Vol. 21, 2012, pp. 110-122. doi:10.1016/j.ecolind.2012.01.012

[91] M. Bell, L. Cifuentes, D. Davis, E. Cushing, A. Gusman Telles and N. Gouveia, "Environmental Health Indicators and a Case Study of Air Pollution in Latin American Cities," Environmental Research, Vol. 111, No. 1, 2011, pp. 57-66.

[92] R. Pinto, J. Patrício, A. Baeta, B. D. Fath, J. M. Neto and J. C. Marques, "Review and Evaluation of Estuarine Biotic Indices to Assess Benthic Condition," Ecological Indicators, Vol. 9, No. 1, 2009, pp. 1-25.

doi:10.1016/j.ecolind.2008.01.005

[93] P. Peduzzi, H. Dao, C. Herold and F. Mouton, “Assessing Global Exposure and Vulnerability towards Natural Hazards: The Disaster Risk Index," Natural Hazards and Earth System Sciences, Vol. 9, No. 4, 2009, pp. 11491159.

[94] C. J. M. Philippart, R. Anadón, R. Danovaro, J. W. Dippner, K. F. Drinkwater, S. J. Hawkins, T. Oguz, G. O'Sullivan and P. C. Reid, "Impacts of Climate Change on European Marine Ecosystems: Observations, Expectations and Indicators," Journal of Experimental Marine Biology and Ecology, Vol. 400, No. 1-2, 2011, pp. 52-69. doi:10.1016/j.jembe.2011.02.023

[95] C. Zhao, G. Fu, X. Liu and F. Fu, "Urban Planning Indicators, Morphology and Climate Indicators: A Case Study for a North-South Transect of Beijing, China," Building and Environment, Vol. 46, No. 5, 2011, pp. 1174-1183. doi:10.1016/j.buildenv.2010.12.009

[96] S. Klasen, "Economic Growth and Poverty Reduction: Measurement Issues Using Income and Non-Income Indicators," World Development, Vol. 36, No. 3, 2008, pp. 420-445. doi:10.1016/j.worlddev.2007.03.008

[97] G. Mastronuzzi and P. Sansò, "The Role of Strong Earthquakes and Tsunami in the Late Holocene Evolution of 
the Fortore River Coastal Plain (Apulia, Italy): A Synthesis," Geomorphology, Vol. 138, No. 1, 2012, pp. 89-99.

[98] T. Inui, T. Yasutaka, K. Endo and T. Katsumi, "GeoEnvironmental Issues Induced by the 2011 off the Pacific
Coast of Tohoku Earthquake and Tsunami," Soil and Foundations, Vol. 52, No. 5, 2012, pp. 856-871.

doi:10.1016/j.sandf.2012.11.008 